\title{
INFORMATION SYSTEM FOR INVENTORY OF GOODS USING PROTOTYPE MODEL
}

\author{
Syahriani 1, Basuki ${ }^{2}$, Luthfi Indriyani ${ }^{3 *}$ \\ Teknik Informatika, Sistem Informasi \\ Sekolah Tinggi Manajemen Informatika dan Komputer Nusa Mandiri \\ www.nusamandiri.ac.id \\ syahriani.yii@nusamandiri.ac.id 1,rangga.basuki7315@gmail.com² \\ Teknologi Komputer \\ Universitas Bina Sarana Informatika \\ www.bsi.ac.id \\ luthfi.lfy@bsi.ac.id 3*) \\ (*) Corresponding Author
}

\begin{abstract}
Abstrak
Management persediaan barang merupakan kegiatan terpenting, karena bila persediaan barang yang terdapat digudang tidak dikelola dengan baik akan memungkinkan terjadinya penurunan keuntungan dan kehilangan pelanggan. PT Andalan Teknik Karetindo Putra Bangsa memiliki kelemahan dalam kegiatan management persediaan barangnya, dimana penyajian informasinya dikerjakan secara manual yaitu melalui proses pencatatan pada sebuah buku, kemudian dipindahkan kedalam aplikasi spreadsheet. Terkadang data yang disampaikan belum akurat, yaitu masih terdapat kekeliruan mengenai stok barang. Pada penenlitian ini, kami menggunakan model perangkat lunak prototype. Pembuatan website ini dibuat guna mengatasi peramasalahan tersebut serta untuk meningkatkan efektifitas dan efisiensi dari kinerja perusahaan. Dimana kami membuatkan 2 hak akses level, yaitu untuk staff gudang dan pimpinan perusahaan. Dengan adanya website ini, staff gudang dapat mengetahui dengan cepat dan akurat ketersediaan barang dan pimpinan dapat langsung mengetahui stok barang yang tersedia digudang serta dapat langsung mencetak laporan persediaan barang tanpa harus bertanya kebagian gudang.
\end{abstract}

Kata kunci: Sistem Informasi; Model Prototype; Persediaan Barang

\begin{abstract}
Inventory management is the most important activity, because if the inventory in the warehouse is not managed properly, it will allow a decrease in profits and loss of customers. PT Andalan Teknik Karetindo Putra Bangsa has weaknesses in its inventory management activities, where the presentation of the information is done manually, namely through the process of recording in a book, then transferred to the Speedsheet application. Sometimes the data submitted is inaccurate, that is, there are still errors regarding the stock of goods. In this research, we used a prototype software model.. Making this website is made to overcome these problems and to increase the effectiveness and efficiency of company performance. Where we make 2 level access rights, namely for warehouse staff and company leaders. With this website, warehouse staff can quickly and accurately find out the availability of goods and leaders can immediately find out the stock of goods available in the warehouse and can immediately print inventory reports without having to ask to the warehouse.
\end{abstract}

Keywords: Information System; Prototype Model; Inventory

\section{INTRODUCTION}

Inventory (inventory of goods) is all customer requests with a minimum inventory of goods(Guslan \& Rodianto, 2019). According to Ristono in Yudha, Sudarma and Mertasana(Alit, Yudha, Sudarma, \& Mertasana, 2017) Inventory (inventory of goods) consists of 3 kinds of inventory, namely inventory of raw materials, semifinished goods and finished goods. The supply of goods must be managed properly, to ensure the smooth traffic of goods

It should be noted that the balance sheet or profit and loss of a company is very influential on 
the company's inventory of goods, be it a trading or manufacturing company (Murdihardjo \& Effendy, 2013). Companies engaged in manufacturing usually have their inventory of raw materials, inprocess goods, finished goods inventories and other materials used in the production process. As for trading companies, the inventory of goods is the merchandise itself (Manengkey, 2014).

In addition, operational problems that often occur in managing stock inventory are when the inventory is small and the demand cannot be fulfilled. Then if the inventory is too large, the company will get a loss (Nawang, Kurniawati \& Duta, 2017). Therefore, the company must be able to plan well in optimizing the number of items ordered, in order to minimize the cost of inventory(Suryani, 2012), Because the inventory of goods has a direct impact on the profits of a company(Tamodia, 2013).

PT Andalan Teknik Karetindo Putra Bangsa is a company in the field of trade and services (rubber raw material). However, this company, in its inventory management activities, still has weaknesses, namely in the process of recording goods, where there is often a mismatch between the stock of goods recorded and its physical (Nuari, 2017) and preparation of inventory reports that still use a manual system, where the recording is carried out in a book then transferred to a number processing application (spreadsheet), where this application has not been said to be optimal when the process of searching for goods data (Meilano, .R, Damanik, 2019). In addition, the stock data provided by the warehouse is sometimes inaccurate and data errors often occur. Judging from these problems, this company needs a new system, in order to support the effectiveness and efficiency of its performance in inventory management activities, namely by creating an appropriate information system and in accordance with the needs. (Fauziah, .S \& Ratnawati 2018).

Previous research has also experienced the same thing, so that an inventory information system was created, in order to make it easier for companies to manage stock items and to provide more effective information. The information system can automatically perform data searches, record incoming and outgoing goods. The stages of making the information system are to collect data (observation, interview and archiving techniques), the design uses Entity Relational Diagrams (ERD), Normalization, Context Diagrams and Data Flow Diagrams (DFD) and use the waterfall model. (Dahlan, 2018).

In addition, PT. Nusatara Sejahtera, where the goods order system still uses manual-calculated stock recording which can create a gap for forgetfulness in the recording process and there is often an imbalance between the number of stock items recorded and the physical stock. From these problems, this company created information systems, in order to manage incoming and outgoing goods data, stock data, ordering goods in one web application using the model.waterfall and depiction of the ongoing process using Data Flow Diagrams (DFD) (Hasanudin, 2018).

It can be concluded, if the company has not been well computerized in the transaction process of its inventory activities (both in the form of recording incoming and outgoing goods and searching for goods data), it can result in a lack of effectiveness and efficiency in company performance, especially in providing information on inventory.

It is known that PT Andalan Teknik Karetindo Putra Bangsa has a very significant number of transactions, so the creation of this inventory information system can help company performance in terms of speeding up the search or tracking of inventory data and making it easier for companies to create inventory reports that can be done at any time.(Mauluddin, .S \& Santini, 2018).

The descriptions above, conclude that in the company PT Andalan Teknik Karetindo Putra Bangsa, there are employee performance that is less effective and efficient in the process of managing inventory, where this affects the turnover and profits the company gets.

On this basis, we conducted this research with the aim of assisting PT Andalan Teknik Karetindo in improving the efficiency and effectiveness of company performance in inventory management activities, so that the existing inventory data can be accurate between the availability of goods in the warehouse and data on the system and can increase company profits.

\section{RESEARCH METHODS}

\section{Data collection technique}

1. Observation

We collect data by making direct observations on this company.

2. Interview

At this stage, we conducted interviews with the Chairman or Owner of PT Andalan Teknik Karetindo Putra Bangsa, in order to obtain accurate information and data.

3. Literature Study

We collected several sources of information for the smooth running of this research, namely 
from book sources found in the public library, books that we buy ourselves or the internet media.

\section{Research Targets / Subjects}

We conducted research at PT Andalan Teknik Karetindo Putra Bangsa, where the company was founded on December 9, 1987. This company has 89 workers, while the President Director of PT Andalan Teknik Karetindo Putra Bangsa is Mr. Muhammad Rohana Suryadharma. This company is engaged in the sale of rubber raw materials, which provides many types of goods including brushes, butterfly vlaue, couping rubber, medical instruments, PU and seals with the best quality and well-known brands.

\section{System Development Model}

In this study, we used a software development model prototype. Prototyping is a software development model used as an early version of the system in the form of a physical working model of the system(Purnomo, 2017).

\section{Collection of Needs}

At this stage, we analyze incoming or outgoing documents (sales documents, purchase documents and inventory documents) related to inventory management activities, in order to identify the format for making the software and the requirements needed in the system development process.

As a result of data collection that has been done, we create 2 access rights, namely:

1. Warehouse staff:

a. Can see item data

b. Can see customer data

c. Can see supplier data

d. Can manage incoming goods transactions

e. Can manage outgoing goods transactions

f. Can manage goods return transactions

g. Can see the stock of goods

2. Manager / Leader
a. Can manage admin data
b. Can manage supplier data
c. Can manage customer data
d. Can view incoming goods reports
e. Can view outgoing goods report
f. Can view payment reports
g. Can see the stock report
h. Can view financial reports
h. Can see the stock report

\section{Design Process}

The process of making the design is tailored to the needs of the user. For this stage, use the Macromedia DreamWever application to design the web interface, the Photoshop application to make the header or footer display attractive, and Macromedia Flash to make the header look even more attractive. Then to design the database system using ERD and LRS and using several UML diagrams to describe the process of its activities.

\section{ERD (Entity Relational Database) design}

Entity Relational Database (ERD) is a model that companies can use to provide an understanding of data (Pahlevi, Mulyani, \& Khoir, 2018).

This dibawan is an illustration of the ERD inventory database system at PT Andalan Teknik Karetindo Putra Bangsa:

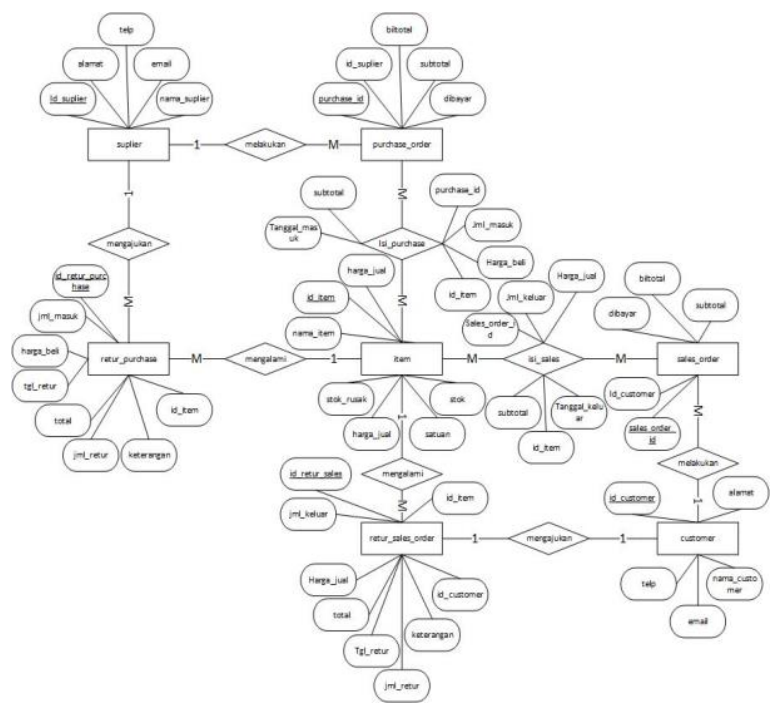

Figure 1.ERD (Entity Relational Database)

\section{LRS (Logical Record Structure) design}

Be caught This is an illustration of the LRS inventory database system at PT Andalan Teknik Karetindo Putra Bangsa:

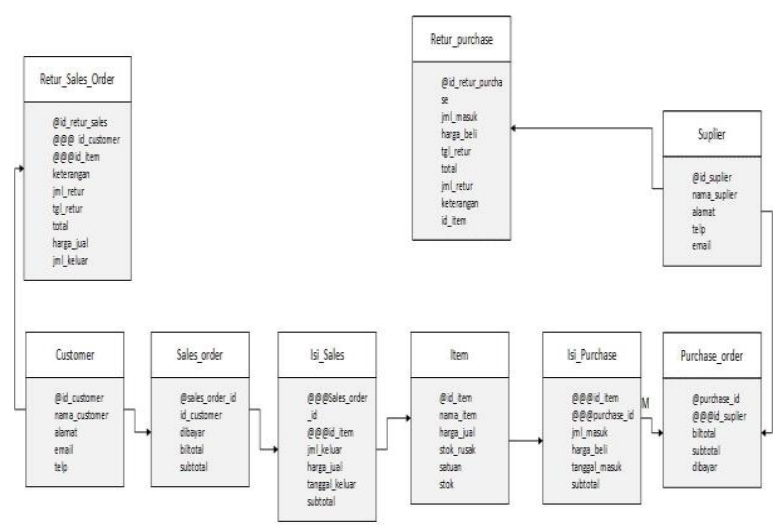

Figure 2.LRS (Logical Record Structure)

\section{UseCase design}


Figure 3 is a warehouse staff diagram usecase design:

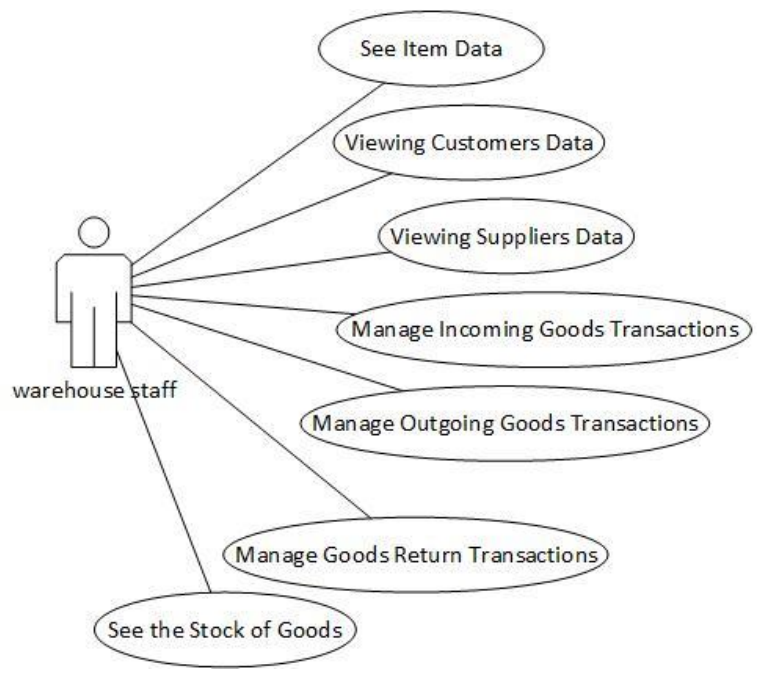

Figure 3. Warehouse Staff Usecase Diagram

\section{Building a Prototype}

In building prototyping, it focuses on presenting the needs of the user. In the website design process, the programming languages HTML, CSS, Javascript and PHP are used. Before the prototyping design is given to the client or user, it is necessary to test the system first using User Acceptance Testing (UAT)

\section{Testing Using User Acceptance Testing (UAT)}

User Acceptance Testing (UAT) is the stage of the testing process where the user provides input and suggestions for system testing.

Table 1. UAT Test Results Warehouse Staff Login Page and Add Items

\begin{tabular}{|c|c|c|c|c|}
\hline Use Case & $\begin{array}{c}\text { Test results } \\
\text { [Successfully } \\
\text { Failed] }\end{array}$ & $\begin{array}{c}\text { Examiner } \\
\text { Name } *\end{array}$ & $\begin{array}{c}\text { Test Date of } \\
\text { Examiner Notes }\end{array}$ & Note \\
\hline $\begin{array}{l}\text { Usecase Test: Login } \\
\text { Description: Verifies users registered to the } \\
\text { system }\end{array}$ & It works & $\begin{array}{l}\text { Muhammad } \\
\text { Rohana } \\
\text { Suryadarma }\end{array}$ & 12 January 2021 & \\
\hline $\begin{array}{l}\text { Test Case: } \\
\text { Username: (input NIP) } \\
\text { Password: admin }\end{array}$ & & & & \\
\hline $\begin{array}{l}\text { Expected results: } \\
\text { - If the login is successful, it will enter the } \\
\text { inventory page } \\
\text { - If the login is not successful, it will not } \\
\text { enter the inventory page and display an } \\
\text { error message through the display }\end{array}$ & It works & Basuki & January 14, 2021 & \\
\hline $\begin{array}{l}\text { Usecase Test: Manage Item Data } \\
\text { Description: Verifies the data input of goods }\end{array}$ & It works & $\begin{array}{l}\text { Muhammad } \\
\text { Rohana } \\
\text { Suryadarma }\end{array}$ & 12 January 2021 & \\
\hline $\begin{array}{l}\text { Test Case: } \\
\text { Item Code: ORG001 } \\
\text { Item Name: Oring } \\
\text { Unit: Pcs } \\
\text { Selling price: } 5500 \\
\text { Purchase price: } 5000\end{array}$ & & & & \\
\hline $\begin{array}{l}\text { Expected results : } \\
\text { - If successfully entered, the message "Saved } \\
\text { Data" will appear } \\
\text { - If the data is not successfully inputted (not } \\
\text { all of them are inputted), the message "Data } \\
\text { is still empty" will appear. Return to the } \\
\text { column that has not been entered. }\end{array}$ & It works & Basuki & January 14, 2021 & \\
\hline
\end{tabular}

\section{Evaluation and Improvement}

Evaluation is carried out by the client, whether this prorotyping is appropriate and appropriate to the client's needs or there are still deficiencies. When it is appropriate, then the fourth stage is taken, namely the implementation process 
JURNAL RISET INFORMATIKA

Vol. 3, No. 2 March 2021
P-ISSN: 2656-1743 |E-ISSN: 2656-1735

DOI: https://doi.org/10.34288/jri.v3i2.218

(implementation) in the company, if it is not suitable, then the prototyping needs to be revised again by repeating steps one, two and three.

\section{RESEARCH RESULTS AND DISCUSSION}

\section{Login Page Views}

In Figure 4 is a display of the login page, this page is the start page if we want to enter the inventory information system access:

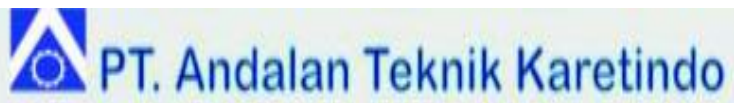

Figure 4. Login Page Form

\section{Main Page Display}

The display in Figure 5 is the main page display on the inventory system, here the user can select the menu according to his needs. For its appearance, it can be seen in Figure 5:

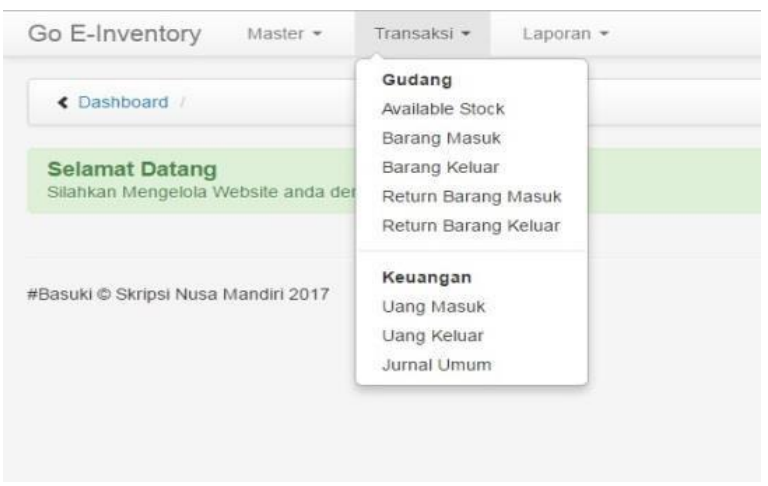

Figure 5 Main Menu Page Form

\section{Add Item Data Page Views}

The Add Item Data page view is used to add item data. The view can be seen in Figure 6:

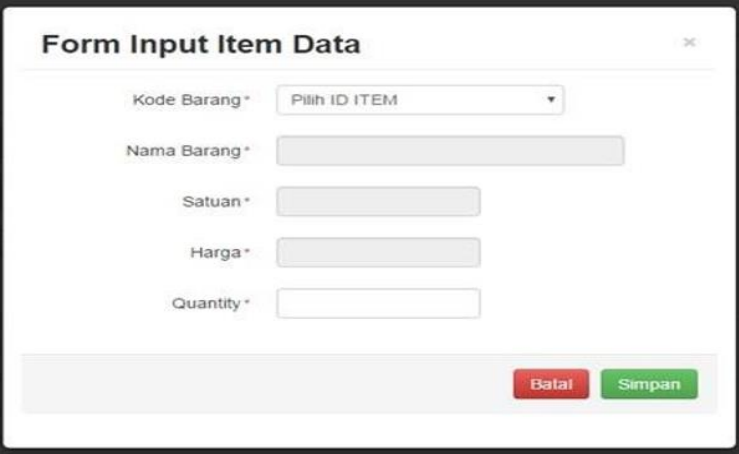

Figure 6. Item Data Page Form

\section{Transaction Page Views}

This page functions to manage incoming goods data along with details of incoming goods and suppliers supplying. The display can be seen in Figure 7:

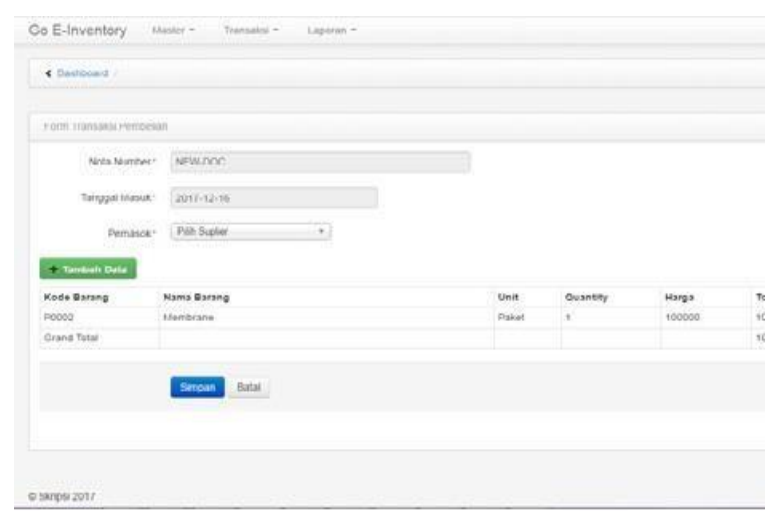

Figure 7. Transaction Page Form

\section{Incoming Goods Report Page Display}

This page functions to generate incoming goods reports based on the selected transaction time period. The display can be seen in Figure 8:

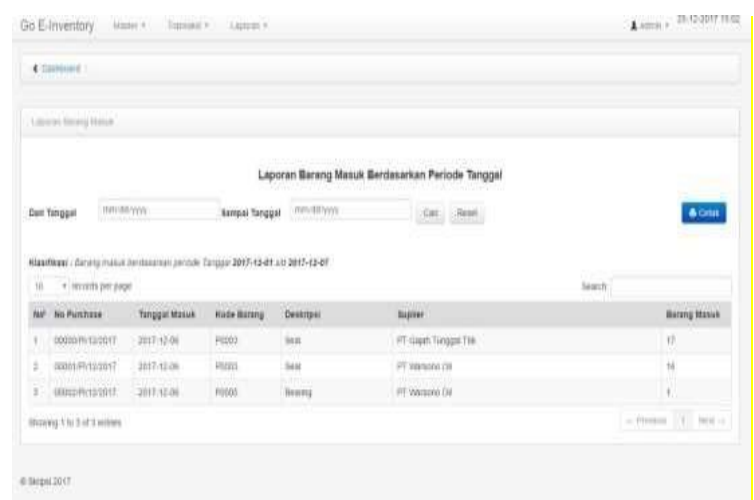

Figure 8.Incoming Goods Report Page Form

The inventory information system that has been designed can improve the smooth performance of the warehouse employee staff in managing inventory stock. In addition, the 
leadership can directly print the required inventory report without having to recap the warehouse staff first. The warehouse employee staff section can easily find out when and how many items to order from the next supplier.

\section{CONCLUSIONS AND SUGGESTIONS}

\section{Conclusion}

PT Andalan Teknik Karetindo Putra Bangsa has a very significant number of transactions, so it is very prone to errors in the calculation of the stock of goods so that an inventory information system is created using a web application. by using the waterfall model in order to help the company's performance in terms of speeding up the search or tracking of inventory data and make it easier for companies to create inventory reports.

\section{Recommendation}

The supply information system with this web application needs improvement to keep up with future application developments. Can use barcode scans to make it easier to update stock data on goods. And it is necessary to periodically back up data to prevent damage or loss of data and to periodically perform virus scans.

\section{REFERENCE}

Alit, I. P., Yudha, P., Sudarma, M., \& Mertasana, P. A. (2017). PERANCANGAN APLIKASI SISTEM INVENTORY BARANG MENGGUNAKAN BARCODE SCANNER BERBASIS ANDROID. $4(2), 72-80$.

Dahlan, A. (2018). Sistem Informasi Inventory Gudang Berbasis Website Pada $\mathrm{Cv}$ El'U Grafika. Sistem Informasi Inventory Gudang Berbasis Website Pada Cv El'U Grafika, 1(12141396), 42.

Fauziah, .S \& Ratnawati. (2018). Penerapan Metode FIFO Pada Sistem Informasi Persediaan Barang. Jurnal Teknik Komputer, 4(1), 98-108.

Guslan, \& Rodianto. (2019). SISTEM INFORMASI INVENTORY DATA BARANG PADA UD . MUTIARA MEUBEL BERBASIS WEB. Jurnal Jinteks, 1(1), 19-28.

Hasanudin, M. (2018). Rancang Dan Bangun Sistem Informasi Inventori Barang Berbasis Web ( Studi Kasus PT . Nusantara Sejahtera Raya ).
Jurnal IKRA-ITH Informatika, 2(3), 24-37.

Manengkey, .N. (2014). Analisis Sistem Pengendalian Intern Persediaan Barang Dagang Dan Penerapan Akuntansi Pada Pt. Cahaya Mitra Alkes. Jurnal Riset Ekonomi, Manajemen, Bisnis Dan Akuntansi, 2(3), 13-21.

Mauluddin, .S \& Santini, .N. (2018). Sistem Informasi Persediaan Dan Penjualan Barang Berbasis Desktop Di D-Net House. Prosiding Seminar Nasional Teknik, Komputer Dan Rekayasa (SAINTIKS), (October).

Meilano, .R, Damanik, .F \& Tanto. (2019). Pengembangan Sistem Informasi Persediaan Barang dengan Metode Waterfall. 2, 30-34.

Murdihardjo, L., \& Effendy, M. (2013). Peranan Pengendalian Intern Persediaan Barang Dagangan Dalam Menunjang Efektivitas Pengelolaan Persediaan. Jurnal Ilmiah Akuntansi Keuangan, 1(1), 45-50.

Nawang, K. \& D. (2017). Left atrial volume and exercise capacity in adult heart transplant recipients. Journal of Cardiothoracic Surgery, 6(1), 233-238. https://doi.org/10.1186/1749-8090-6-9

Nuari, O. \&. (2017). Rancang Bangun Sistem Informasi Persediaan Barang Berbasis Web Dengan Metode Fast(Framework For The Applications). Jurnal PILAR Nusa Mandiri, Vol. 13, N(2), 261-266. Retrieved from http://ejournal.nusamandiri.ac.id/ejurnal/in dex.php/pilar/article/view/705

Pahlevi, O., Mulyani, A., \& Khoir, M. (2018). Sistem Informasi Inventori Barang Menggunakan Metode Object Oriented Di Pt . Livaza Teknologi Indonesia Jakarta. 5(1).

Purnomo, D. (2017). Model Prototyping Pada Pengembangan Sistem Informasi. J I M P Jurnal Informatika Merdeka Pasuruan, 2(2), 54-61.

https://doi.org/10.37438/jimp.v2i2.67

Suryani, I. \&. (2012). Analisis Pengendalian Persediaan Produk Dengan Metode EOQ Menggunakan Algoritma Genetika untuk Mengefisiensikan Biaya Persediaan. 1.

Tamodia, .W. (2013). Evaluasi Penerapan Sistem Pengendalian Intern Untuk Persediaan Barang Dagangan Pada Pt. Laris Manis Utama Cabang Manado. Jurnal Riset Ekonomi, Manajemen, Bisnis Dan Akuntansi, 1(3), 20-29. 